\title{
The molecular changing mechanism of Ampicillin-Sulbactam resistant Staphylococcus aureus towards Methicillin resistant Staphylococcus aureus
}

\author{
Mieke Hemiawati Satari \\ Department Oral Biology \\ Faculty of Dentistry Padjadjaran University \\ Bandung - Indonesia
}

\begin{abstract}
The aim of this study was to determine the molecular changing of S.aureus, which is resistant to Ampicillin-Sulbactam and then become resistant to Methicillin as a result of improper dosage. The study was conducted by isolating Ampicillin-Sulbactam resistant and Methicillin Resistant S.aureus (MRSA), afterwards an amplification process was performed by PCR (Polymerase Chain Reaction.) to isolate the betalactamase enzyme regulator and PBP 2 a genes. The result of this research showed that there were a deletion of few amino acids from the regulator gene, and a suspicion that the DNA sequence had been substituted from PBP 2 gene into PBP $2 a$ (gen mec). This process had formed MRSA.
\end{abstract}

Key words: S.aureus, betalactamase gene, PBP 2 a gene

Correspondence: Mieke Hemiawati Satari, c/o: Bagian Oral Biologi, Fakultas Kedokteran Gigi Universitas Padjadjaran. Jln. Sekeloa Selatan I Bandung, Indonesia.

\section{INTRODUCTION}

Until now, infection is still a prevalent problem especially in developing countries. One of dental caused infections is periapical abscess. Prolonged infection will cause jaw osteomyelitis with Staphylococcus aureus (S. areus) as the main bacteria.

In constant efforts to cope with infection caused by $\mathrm{S}$. aureus, several antibiotics had been used, among others the Betalactam group. However, the present condition revealed many bacteria are resistant to Betalactam. To overcome the resistance, Betalactam is mixed with Betalactamase inhibitor, in this case Ampicillin with Sulbactam complying to antibiotic-consumption-strict-rules of correct doses, correct indication, and correct bacteria. Should this rules be violated, therapy becomes difficult and expensive, and also escalating resistance.

Based on a research by Satari ${ }^{1}$ from 94 clinical isolates, 79\% was Ampicillin resistant, 53\% was AmpicillinSulbactam resistant and out of this $53 \%$ resistance, $38 \%$ was resistant towards Methicillin causing bacteria resistance to many antibiotics.

From an empirical 7 years study (1986-1993) conducted at the Microbiology Department of School of Medicine, University of Indonesia, it was revealed that S.aureus pattern of resistance had changed to multiresistance. ${ }^{2}$ Lyon and Skuray ${ }^{3}$ had proven that S.aureus was resistant to 20 antibiotics.
According to on Brooks, ${ }^{4}$ since 1961 the multiresistant S. aureus has caused health problems particularly at health centers that can be fatal. The multiresistant S. aureus was later known as resistant to Methicillin S. aureus (MRSA). In molecular process, the forming of MRSA was initiated by a mutation of PBP 2 which was a transpeptidase enzyme functioning in forming a murein bag of peptidoglican, to become PBP 2a which had low affinity towards Betalactam antibiotic group. The aim of this research was to molecularly analyze the influence of S.aureus resistance pattern against Ampicillin-Sulbactam to form MRSA. This research gave scientific contribution to understand the resistibility process at molecular stage.

\section{MATERIALS AND METHOD}

The sample was taken from isolate $\mathrm{S}$. aureus which was resistant against Ampicillin-Sulbactam and Methicillin, complying with the criteria as follows: 1) producing Betalactamase enzyme; 2) producing total DNA isolation; 3) PCR fragment gene regulator technique (blaI and blaRI• using 2 primary pairs) and fragment (PBP 2a (gen mec) • using 1 primary pair) could be well isolated.

The primary which was used to isolate Betalactamase enzyme regulator gene (blaRI and blaI) was designed by Okamoto, Okubuta and Inoue. ${ }^{5}$ 
Forward bla Z: primary sense Reverse blaRI: primary antisense

blaI:

\section{P1: 5'ACTCTTTGGCATGTGAACTG 3' \\ P3: 5' GGACAAATCTATCGGCTTCT 3' \\ P4: 5' TGAGTTGAGTCGCAGTATAG 3' \\ P5: 5' CATAACATCCCATTCAGCCA 3' \\ P6: 5' AACTTTTCAATGTTCCCCTCC 3'}

The primary which was used to isolate gen mec was designed by Murakami, Minamide. ${ }^{6}$

Forward : 5' AAAATCGATGTTAAAGGTTGGC 3'

Reverse : 5' AGTTCTGCAGTACCGGATTTGC 3'

The research material was isolate $\mathrm{S}$. aureus which was resistant to Ampicillin-Sulbactam and Methicillin. It was obtained from the Microbiology Clinic of Hasan Sadikin General Hospital/School of Medicine Padjadjaran University and School of Medicine Diponegoro University.

The chemical substance to totally isolate DNA: Tris HCL $50 \mathrm{mM}$ containing EDTA $5 \mathrm{mM}, \mathrm{NaCl} 50 \mathrm{mM}$, lysostapin $20 \mu \mathrm{g} / \mathrm{ml}$ and Rnase $200 \mu \mathrm{g} / \mathrm{ml}$. The total DNA isolation was performed with Tokue and Shoji ${ }^{7}$ technique.

The chemical substance for PCR technique were: buffer lysis, PCR kit core system (Promega), Primary (P1-P6) and primary mec. BlaRI and blaI isolation with PCR technique using Primary (P1-P6) under PCR condition i.e.: 1) denaturation process $94^{\circ} \mathrm{C}$ for 4 minutes, 2) $94^{\circ} \mathrm{C}$ denaturation cycle stage in 30 seconds, 3) $50^{\circ} \mathrm{C}$ primary attachment stage in 30 seconds, and 4) $72^{\circ}$ polymerisation stage in 2 minutes. Polymerase chain reaction (PCR) was done in 40 cycles with $72^{\circ}$ stabilizing stage.

The chemical substance for sequensing technique was ABI PRIMS Dye Terminator Cycle Sequensing Ready Kit (Perkin Elmer Corporation). The equipments for microbiologic examinations were Eppendorf tube, $25^{\circ} \mathrm{C}$ and $-4^{\circ} \mathrm{C}$ ultra centrifugation, vortex mixter, E-C minicell, PCR machine, transilluminator with ultraviolet, polaroid, DNA sequensing ABI Prims 377.

\section{RESULTS}

Amplification result of blaZ, blaRI and blaI genes using 4 primary pairs can be seen on figure 1 .

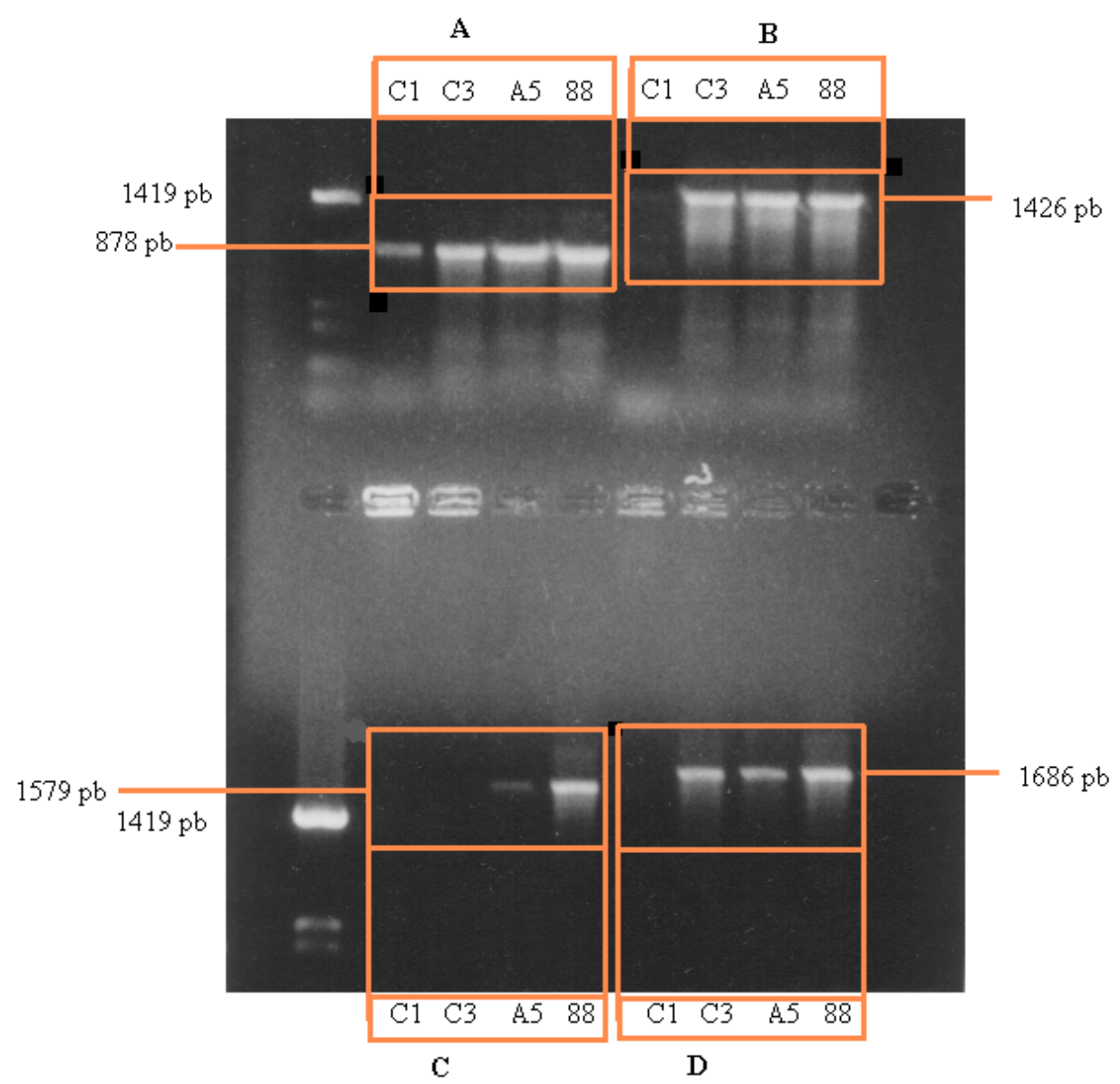

Figure 1. Electrophoresis PCR product utilizing P1-P6 to amplify blaZ, bla RI and blaI gene fragments. 
Hinfl (pUC19) was the marker used to give restriction results sized 1419,517,396,214 and $65 \mathrm{pb}$.

Figure A: isolate using primary P1 - P3 $\rightarrow 878 \mathrm{pb}$

Figure B: isolate using primary P1 - P4 $\rightarrow 1426 \mathrm{pb}$

Figure C: isolate using primary P1 - P5 $\rightarrow 1579$ pb

Figure D: isolate using primary P1 - P6 $\rightarrow 1686 \mathrm{pb}$

Primary P1-P6 with primary internal P3, P4, P5 were used in this research. P1-P3 had 878pb, amplifying blaZ which was a Betalactamase enzyme structure gene. P1-P4 had 1426pb, amplifying blaZ and part of blaRI. P1-P5 had $1579 \mathrm{pb}$, amplifying blaZ, blaRI and part of blaI. P1-P6 had $1686 \mathrm{pb}$, amplifying blaZ, bla RI and blaI.

To study the deletion of regulator gene, which later on was suspected being fusion with gen mec, a sensitivity test was performed towards S. aureus Ampicillin-Sulbactam resistant with Methicillin. Thirty eight percent of samples were resistant to Methicillin. After amplifying gen mec a, the result was an amplification with $517 \mathrm{pb}$ length.

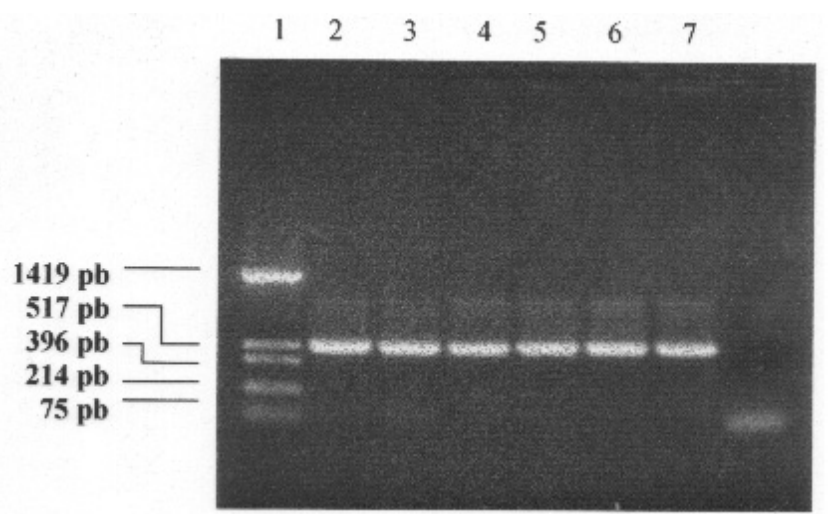

Figure 2. Gen mec detection of MRSA

\section{Column}

1. Marker pUC19/Hinfl

2. PCR isolate A5 product

3. PCR isolate A5 product

4. $\mathrm{PCR}$ isolate $\mathrm{C} 3$ product

5. PCR isolate $\mathrm{C} 3$ product

6. PCR isolate 88 product

7. PCR isolate 88 product

8. Negative control

\section{DISCUSSION}

Using P1-P3, the output of blaZ gene fragment amplificaton could be isolated in accord to the length of the structured gene which was $878 \mathrm{pb}$ due to the relatively stable blaZ, and from a homology output with S. aureus Tn 552, where no mutation occurred. All these outputs showed that to the resistance of S. aureus against AmpicillinSulbactam was not caused by the structured gene mutation.

An amplification output of blaRI and blaI genes using two primary pairs of P1-P5 was 1579pb from the expected 1960pb. While with P1-P6, the output was 1686pb from the expected $2223 \mathrm{pb}$. This was assumed due to a deletion of some nucleotides from both genes resulting in disturbed function of the regulator gene for betalactamase enzyme production i.e. a hyperproduction. This hyperproduction was the cause of the resistance of $\mathrm{S}$. aureus against Ampicillin-Sulbactam.

Hyperproduction took place evoked by nucleotides changes on regulator genes where they transmitted (blaRI) and received signal (blaI). Wiederman and Peter ${ }^{8}$ stated that should a regulator gene be inactive as a result of several nucleotides deletion, then the production of Betalactamase enzyme multiplied enormously.

According to Okamoto ${ }^{5}$ and Murray ${ }^{9}$ a deletion of 150 nucleotides on the tip of the regulator gene could vanish its regulating function, a change of production characteristic occurred, that was from inductive to constitutive production manifolding Betalactamase output in 50-100 times. While Lewis, Curnok and Dyke ${ }^{10}$ clarified that MRSA was formed due to the fusion between the regulator gene and the structural PBP2 gene which afterward expressed a PBP 2a gene with a low affinity towards Ampicillin-Sulbactam. The shaping of PBP 2a was the reason for the resistibility of S.aureus against several antibiotics, this was later known on as MRSA.

The conclusion of the research revealed that the usage of antibiotics in particular of Ampicillin-Sulbactam mixture, should stick to certain regulations to avoid resistance. The resistance against Ampicillin-Sulbactam, phenotypically was caused by a hyperproduction of Betalactamase enzyme. Genotypically, the hyperproduction was due to the deletion of several nucleotides of regulator genes. It was assumed that the vanished nucleotide fusioned with PBP 2 becoming PBP 2a. The fusion happened because the regulator gene with PBP 2 gene had formed a tertiary DNA structure Kernodle. ${ }^{11}$

\section{REFERENCES}

1. Satari MH. The molecular phenomenon of betalactamse enzyme hyperproduction on resistant Staphylococcus aureus against Ampicillin Sulbactam. Desertation. Bandung: Postgraduate Program Padjadjaran University; May 2002. p. 1.

2. Sudarmono P, Radji M. Features of typhoid fever in Indonesia, Singapore. World Scientific 1994; 11-6.

3. Lyon BK, Skuray R. Antimicrobial resistance of S. aureus genetic basis. Microbiology Reviews, Dept of Microbiology Monash University, Victoria- Australia March 1987; 12(3):94-8.

4. Brooks GF, Butel JS, Morse SA. Staphylococcus. In: Jawetz, Melnick, Adelberg, editors. Medical microbiology. $21^{\text {th }}$ ed. Connecticut: Appleton \& Lange; 2001. p. 197-202.

5. Okamoto R, Okubuta Y, Inoue R. Detection of gene regulating Betalactamase productionin S. aureus. Antimicrobial Agents and Chemotherapy 1996 November; 40(11):2550-4.

6. Murakami K, Minamide W. PCR detection of methicillin-resistant S. aureus. Diagnostic Moleculer Microbiology, BIOS Scientific Pub Co; 1994. p. 76-82.

7. Tokue Y, Shoji S. Comparison of polimerase chain reaction assay. Antimicrobial Agents and Chemotherapy 1992 January; 44(6):6-9.

8. Wiederman B, Peter GK. Induction of Betalactamase in Gram positif bacteria. Diag Microbial \& Infectious Disease1989; 12:131-7.

9. Murray BE. Betalactamase producing S. aureus. J Antimicrobial Agents \& Chemistry 1992 April; 873-9.

10. Gregory PD, Lewis RA, Dyke KGH, Curnock SP. Study represor (BlaI) betalactamase synthesis of Staphylococcus aureus. Moleculer Microbiology 1997; 24 (5):1025-37.

11. Kernodle DJ. Mechanism of resistence to betalactam antibiotic in Gram positive pathogens. American Society for Microbiology 2000; 609-23 